Article

\title{
Study on Sludge and Dissolved Oxygen Distribution in a Full-Scale A2/O Oxidation Ditch
}

\author{
Chengyi Li ${ }^{1}$, Zhao Han ${ }^{2}$, Yuquan Zhang ${ }^{3, *(D)}$, Yuan Zheng ${ }^{3}$, Hepeng Zhang ${ }^{4}$ and \\ Emmanuel Fernandez-Rodriguez 5 (D)
}

1 College of Water Conservancy and Hydropower Engineering, Hohai University, Nanjing 210098, China; vghead@163.com

2 Hongping Pumped Storage Co., Ltd., Yichun 330600, China; zhaohan88a@outlook.com

3 College of Energy and Electrical Engineering, Hohai University, Nanjing 210098, China; zhengyuan@hhu.edu.cn

4 Luoyun Management Division, Suqian 223899, China; zhangheping88a@outlook.com

5 Technological Institute of Merida, Technological Avenue, Merida 97118, Mexico; fratellosole22@hotmail.com

* Correspondence: zhangyq@hhu.edu.cn

check for updates

Citation: Li, C.; Han, Z.; Zhang, Y.; Zheng, Y.; Zhang, H.; Fernandez-

Rodriguez, E. Study on Sludge and Dissolved Oxygen Distribution in a Full-Scale A2/O Oxidation Ditch.

Water 2021, 13, 2776

https://doi.org/10.3390/w13192776

Academic Editor: Jacek Mąkinia

Received: 3 August 2021

Accepted: 24 September 2021

Published: 6 October 2021

Publisher's Note: MDPI stays neutral with regard to jurisdictional claims in published maps and institutional affiliations.

Copyright: (c) 2021 by the authors. Licensee MDPI, Basel, Switzerland. This article is an open access article distributed under the terms and conditions of the Creative Commons Attribution (CC BY) license (https:/ / creativecommons.org/licenses/by/ $4.0 /)$.

\begin{abstract}
The distribution of velocity, sludge, and dissolved oxygen in a full-scale anaerobic-anoxicoxic (A2/O) oxidation ditch was numerically simulated under three rotation speed scenarios. The viscosity and settling rate of activated sludge were defined through a user-defined function (UDF), and the sludge phase was calculated using the mixture multiphase flow model. Dissolved oxygen (DO) was set as a user-defined source (UDS) and its generation and consumption rates were defined with UDFs. The relationship between velocity and sludge concentration was found to be contradictory, with dead zones leading to large sludge concentrations at the bottom of the oxidation ditch (OD), but not at the middle-curved wall of the anoxic pool. The flow rate of the reflux slot and aerator oxygenation rate were checked and correlated with DO concentrations in the anaerobic pool. The majority of the large sludge concentrations were concentrated in the biological selection pool and these remained constant with bed height. With reduced propeller and agitator rotation speed, the sludge concentrations reduced in the biological selection pool, but increased in the anaerobic and anoxic pools.
\end{abstract}

Keywords: A2/O oxidation ditch; sludge; dissolved oxygen; computational fluid dynamics; multiphase flow

\section{Introduction}

Preserving clean fresh water resources plays a pivotal role in a city's economics, industrial and commercial growth, and sustainability. Sewage treatment has been adopted in many countries on the grounds of reducing the nutrient water pollution and risk of human disease [1], by the elimination of harmful substances from municipal wastewater, prior to its discharge into the environment. Sewage treatment is generally classified into primary, secondary, and tertiary processes, with some plants co-producing biogas, leaving the potential for energy-autonomous treatment plants [2]. The primary process is a sedimentation stage; the second, a biological nutrient removal method; and the tertiary, an additional treatment for proper disposal in delicate regions. The anaerobic-anoxicoxic process $(\mathrm{A} 2 / \mathrm{O})$ is an important biological treatment, based on the degradation of organic contaminants using pre-arranged microorganisms, and it is commonly used for secondary or tertiary sewage treatment, as well as for reclaimed water reuse [3,4]. Due to its features, it is able to remove excessive nitrogen and phosphorus, using low biosolid byproducts, named sludge, and it is suitable for wastewater applications with a high content of organic contaminants. The process can be integrated into an OD (oxidation ditch); a circular basin with two adjoined channels, in the form of loop, with two curved 
walls at the end, designed to remove sludge through circulation by rotators. Certain design variants produce a larger denitrification and phosphorus removal effect, compared with the traditional oxidation technology. It has a universal application in the treatment of urban and industrial wastewater, because of its structural simplicity, short total hydraulic residence time, low operating costs, small control complexity, and limitation of sludge swelling. As a result, the A2/O oxidation ditch is one of the mainstream technologies of sewage treatment in China [5,6], a country with highly-populated urban areas and an upcoming water crisis [7].

Since an OD covers a large area, the pool is deep and the flow movement is irregular, hindering the gathering of in-depth experimental information. Furthermore, studies based on wastewater treatment plants (WWTP) often suffer from a paucity of data acquisition, since these are usually collected at the inlet and outlet, with little attention paid to the internal flow patterns, sludge distribution, and DO (dissolved oxygen) [8]. Some authors have attempted to solve this by understanding the relative importance of the flow factors and relations at laboratory scales $[9,10]$. For example, Mir et al. [11] conducted a one-tenth model scale of a real OD to observe the process of sludge setting. Chen et al. [12] arranged a simplified model, 15 times smaller than a real OD, and observed its internal flow pattern through an acoustic doppler velocimeter (ADV). However, the previous method is limited by its high cost and discrepancy with actual OD situation. Alternatively, programs based on computational fluid dynamics (CFD) can determine the factors affecting the efficiency of the OD and provide results with different scenarios, and thus remain the best and most economical method of simulating the inner state of OD.

For many years, the designs of OD in most sewage treatment plants were based on previously existing plant designs and some empirical formulas [13], until the emergence of, and greater confidence in, CFD methods in recent decades.[14] Generally, a simple single-phase CFD calculation is used to optimize the OD, due to its partial prediction of areas prone to sludge silting, based on the lower flow rate areas at the bottom of the OD. In reality, some parts of the ditch contain sludge concentrations not directly related to the flow rate; therefore, the analysis can be misleading. The multiphase flow model overcomes this limitation and is generally used to simulate active sludge [12]. As active sludge, compared with sand, floats in a flocculent state, the slip velocity between phases is an important basis for correctly describing its settling, and its definition is a matter of ongoing discussions. Littleton et al. $[15,16]$ introduced the activated sludge model no. 2 (ASM2) to calculate the sedimentation rate by using a double-index sludge sedimentation model $[11,17]$. The viscosity varied according to the local concentration of sludge. Whereas Zhang et al. [18], in order to acquire a better understanding on the sludge distribution, used the sludge viscosity formula [19] in their model, and the results were found to be influenced by the action of the propellers and water depth.

There are many methods of simulating DO in OD. Gases in aeration in oxidation trenches can be directly simulated, and multiphase flow calculations can be performed using the Eulerian-Eulerian multiphase model $[20,21]$. Likewise, the transport of dissolved oxygen can be simulated using the transport and reaction model, and consumption of DO in OD, by the BOD-DO model $[8,22]$. The aeration process, however, is more difficult to account for. The gas content in the water during multiphase flow initially must be calculated, in order to obtain the DO in the liquid, using the formula of DO transfer in the gas [23-25].

In reviewing the above literature and the lack of clarity about sewage flows, a full-scale A2/O OD is calculated in this paper using the mixture multi-phase model to study the relationship between velocity, sludge concentration, and $\mathrm{DO}$ in different zones of the $\mathrm{A} 2 / \mathrm{O}$ OD. The viscosity and settling rate of the activated sludge was set with a user-defined function (UDF) and the DO with a user-defined source (UDS), whilst the consumption phase of DO used a half-saturation formula. The accuracy of the calculation was verified by experiments. Analyses were made of the relationship of DO in the reflow hole and added oxygen in the aerator with the total DO in the OD, as well as of the flow rate with sludge 
concentration. The distribution of DO in different parts of the OD was evaluated, and the influence of velocity, sludge concentration, and DO was studied by changing the rotation speed of the agitators and propellers within the OD.

\section{Materials and Methods}

\subsection{Introduction of the $A 2 / O O D$}

The A2/O OD is located in Xiaoxian County, Shandong Province, China, and is $6 \mathrm{~m}$ deep $(\mathrm{H}), 18.6 \mathrm{~m}$ wide, and $62.6 \mathrm{~m}$ long, as depicted in Figure 1. In the treatment process, the wastewater goes through four sections within the OD. First, it enters at the top of the biological selection pool, in the lower-left part; measuring $6 \mathrm{~m}$ wide by $9 \mathrm{~m}$ long and containing two agitators with diameter a of $0.4 \mathrm{~m}$, hub height of $1.3 \mathrm{~m}$, and rotation speed of $550 \mathrm{rpm}$. Afterwards, it circulates into the anaerobic pool, just behind the biological selection pool, containing two side-by-side propellers of diameter $1.84 \mathrm{~m}$, rotation speed of $61 \mathrm{rpm}$, and hub height $1.8 \mathrm{~m}$.

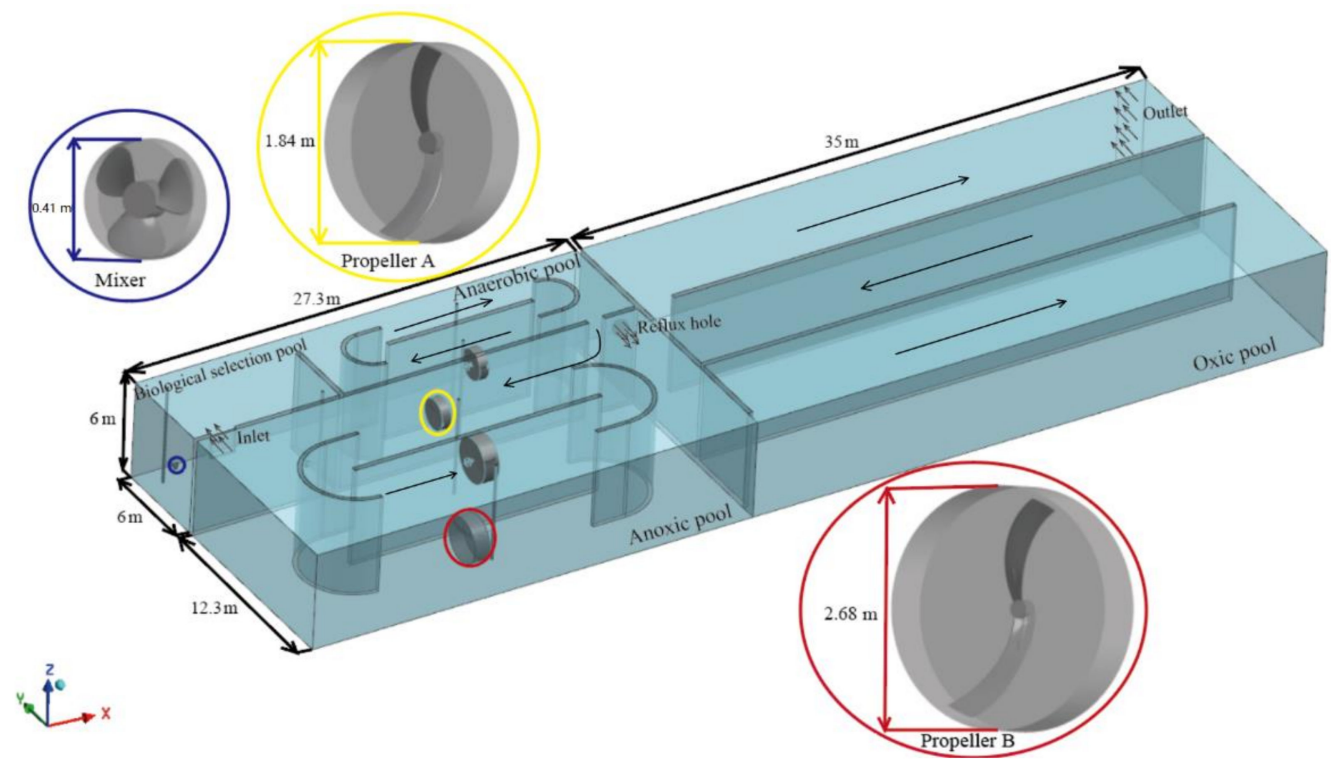

Figure 1. Set up of the A2/0 OD.

The flow then leaves at the rear rightward end and enters the anoxic pool, which has two propellers of $2.68 \mathrm{~m}$ diameter, with a hub height of $1.8 \mathrm{~m}$ and rotation speed of $39 \mathrm{rpm}$. The anoxic pool measures 1.5-times the length and 2-times the width of the similarly-shaped anaerobic pool. Finally, the flow enters the oxic pool, in the upper end of the OD, with diaphragm aerators at the bottom to produce DO; the oxygenation rate is $5 \mathrm{mg} / \mathrm{L} \cdot \mathrm{s}$. To further treat the remaining contaminants, internal recirculation is established between the anoxic and oxic pool, prior to its discharge at the rear-left end of the tank.

\subsection{Multiphase Flow Model}

The calculation was carried out using the CFD software Ansys Fluent. The mixture model with a k- $\varepsilon$ model was used, having good applicability to turbulence model selection and the simulation of several phase flows of different rotation speeds by having a local equilibrium on a short space-time scale. Since the coupling between phases is very strong, it is suitable for simulating activated sludge. In this approach, the continuity equation for the phases is:

$$
\frac{\partial}{\partial t}\left(\rho_{m}\right)+\nabla \cdot\left(\rho_{m} \bar{v}_{m}\right)=0
$$

where $\rho_{m}$ is the mixture density, $\mathrm{kg} / \mathrm{m}^{3}$, and $\bar{v}_{m}$ is the average velocity of the mass, $\mathrm{m} / \mathrm{s}$.

The momentum equation for the mixture can be obtained by summing the momentum equations of the individual phases, as follows: 


$$
\frac{\partial}{\partial t}\left(\rho_{m} \bar{v}_{m}\right)+\nabla \cdot\left(\rho_{m} \bar{v}_{m}^{2}\right)=-\nabla \mathrm{p}+\nabla \cdot\left[\mu_{m}\left(\nabla \bar{v}_{m}+\nabla \bar{v}_{m}^{T}\right]+\rho_{m} \bar{g}_{m}+\vec{F}+\nabla \cdot\left(\sum_{k=1}^{n} \alpha_{k} \rho_{k} \bar{v}_{d r, k}^{2}\right)\right.
$$

where $\mu_{m}$ is the viscosity coefficient of the mixture, Pa.s, $\vec{F}$ is volume force, $\mathrm{N}, n$ is number of phases, $\alpha_{k}$ is the volume fraction of the kth phase, $\rho_{k}$ is the density of the $k$ th phase, $\mathrm{kg} / \mathrm{m}^{3}$, and $\bar{v}_{d r . k}$ is the drift velocity of the $\mathrm{kth}$ phase, $\mathrm{m} / \mathrm{s}$.

The relation between the phase slip velocity and drift velocity is

$$
\bar{v}_{d r . p}=\bar{v}_{q p}-\sum_{k=1}^{n} \frac{\alpha_{k} \rho_{k}}{\rho_{m}} \bar{v}_{q k}
$$

where $\bar{v}_{d r . p}$ is the slip velocity of the second phase $(p)$ relative to the main phase $(q), \mathrm{m} / \mathrm{s}$.

According to the continuity equation of the second phase $(p)$, the volume fraction equation of the second phase is:

$$
\frac{\partial}{\partial t}\left(\alpha_{p} \rho_{p}\right)+\nabla \cdot\left(\alpha_{p} \rho_{p} v_{m}\right)=-\nabla \cdot\left(\alpha_{p} \rho_{p} v_{d r, p}\right)
$$

\subsection{Definition of Sludge}

The mixture model adopts a two-phase flow representation. The first-phase flow is the water-liquid, and the second is the activated sludge mentioned above. The density of water-liquid is $998.2 \mathrm{~kg} / \mathrm{m}^{3}$, and the viscosity is $0.001003 \mathrm{~Pa} \cdot \mathrm{s}$. The sludge density is $1050 \mathrm{~kg} / \mathrm{m}^{3}$, and its viscosity is a function related to temperature and sludge concentration. According to Leighton et al. [26] and Zhang et al. [19], the applicability and conformity of the index model to activated sludge is high, and its expression is

$$
\mu_{s v}=0.63 \exp \left(\frac{120}{T}+0.078 M L S S\right)
$$

where $\mu_{s v}$ is sludge viscosity, $10^{-3} \mathrm{~Pa} \cdot \mathrm{s}, T$ is absolute temperature, $K$, and MLSS represents the sludge concentration, $\mathrm{g} / \mathrm{L}$.

The sedimentation rate of sludge in clean water is obtained according to the doubleindex sludge sedimentation model [16]. The given procedure initially consists in measuring the sedimentation rate of the sludge under different concentrations and then obtaining the coefficients using best-fit procedures, as follows:

$$
V_{s}=0.004 \times\left(e^{-0.46 x}-e^{-1.86 x}\right)
$$

where $V_{s}$ is the sludge sedimentation rate, $\mathrm{m} / \mathrm{s} ; x$ indicates sludge concentration, $\mathrm{g} / \mathrm{L}$.

Equations (5) and (6) were applied by UDF and introduced into ANSYS Fluent. The viscosity and settling rate of the activated sludge were defined, where the particle diameter of sludge was $0.4 \mathrm{~mm}$.

\subsection{Definition of $D O$}

Since DO is not in a simple gas state within water, it is more appropriate to define it by using a UDS rather than a multi-phase flow approach. The transmission equation of UDS is:

$$
\frac{\partial p_{i} \varphi}{\partial t}+\nabla \cdot\left(\vec{J} \varphi_{i}-\Gamma_{i} \nabla \varphi_{i}\right)=S_{\varphi i}
$$

Converting Equation (7) into a unit volume of the control body, it becomes:

$$
\begin{gathered}
\int \frac{\partial(p \phi)}{\partial t} d V+\int \rho \phi u \cdot \mathrm{ndA}-\int \Gamma \nabla \phi \cdot n d A=\int S d V \\
\text { transient convection diffusion source }
\end{gathered}
$$


where $\phi$ is the dissipation function, $U(\mathrm{u}, \mathrm{v}, \mathrm{w})$ is the fluid velocity vector, $\Gamma$ is the diffusion coefficient, $\mathrm{m}^{2} / \mathrm{s}$, and $S$ is the source term representing the creation or destruction of $\phi$.

The sum of oxygen demand for biochemical oxygen demand (BOD) and ammonia nitrogen and sludge respiration in the oxic pool provides the total amount as:

$$
\mathrm{AOR}=\mathrm{a} \times \mathrm{Q} \times \Delta \mathrm{C}_{\mathrm{BOD}}+\mathrm{b} \times \mathrm{Q} \times \Delta \mathrm{C}_{\mathrm{NH} 3-\mathrm{N}}+\mathrm{c} \times \mathrm{V}_{A} \times \mathrm{MLSS}_{A}
$$

where AOR is the actual oxygen demand, $\mathrm{kgO}_{2} / \mathrm{d}$; a is the oxygen demand for each removal of $1 \mathrm{~kg} \mathrm{BOD}$, which is $0.7 \mathrm{~kg}$; $\mathrm{Q}$ is the daily average water mass flow $\mathrm{kg} / \mathrm{s}, \Delta \mathrm{C}_{\mathrm{BOD}}$ is the BOD concentration difference of inlet and outlet, which is $160 \mathrm{mg} / \mathrm{L} ; \mathrm{b}$ is oxygen demand per kilogram of oxic sludge for its own respiration, which is $0.16 \mathrm{~kg}$; MLSS $_{\mathrm{o}}$ is sludge concentration of oxic pool, $\mathrm{g} / \mathrm{L}$; $\mathrm{V}_{\mathrm{o}}$ is the volume of the oxic pool, $\mathrm{L}$; c is oxygen demand per kilogram of ammonia and nitrogen removed, which is $4.57 \mathrm{~kg}$; and $\Delta \mathrm{C}_{\mathrm{NH} 3 \mathrm{~N}} \mathrm{~N}$ is the difference in ammonia and nitrogen concentration between the inlet and outlet.

In practice, several factors must be considered to quantify the oxygen demand in the OD, including the local operating pressure, water quality, and temperature, as well as the different needs for discharging the treated water into the ditch. Therefore, the standard oxygen demand (SOR) is:

$$
\mathrm{SOR}=\frac{A O R \times C s_{20}}{\alpha \times 1.024^{(t-20)}\left(\beta \rho C s_{\text {Tmax }}-C_{1}\right)}
$$

where $T_{\max }$ is the maximum designed water temperature, which is $25^{\circ} \mathrm{C}^{\circ} \mathrm{Cs}_{20}$ is the saturated DO concentration at $20^{\circ} \mathrm{C}$ under standard atmospheric pressure, which is $9.17 \mathrm{mg} / \mathrm{L}$; $\mathrm{Cs}_{\mathrm{Tmax}}$ is saturation DO concentration at the maximum designed water temperature, $\mathrm{mg} / \mathrm{L}$; $\alpha$ is the correction factor of the oxygen transfer coefficient in sewage, which is $0.85 ; \beta$ is the correction factor for saturated DO concentration in sewage, which is 0.95 ; $\mathrm{t}$ is the temperature, ${ }^{\circ} \mathrm{C}$; $\rho$ is the correction factor for air pressure, which is 1 ; and $C_{1}$ is the concentration of $\mathrm{DO}$ in the sewage, $\mathrm{mg} / \mathrm{L}$.

The rate of DO consumption can be expressed in terms of a semi-satiation formula, according to the work of Littleton et al. $[15,16]$.

$$
\text { OUR }=\frac{C_{c v}}{C_{c v}+1} \times O U R_{\max }
$$

where $C_{c v}$ is the concentration of DO in the control volume, $\mathrm{mg} / \mathrm{L}$, and $O U R_{\max }$ is the maximum consumption rate of $\mathrm{DO}, \mathrm{mg} /$ Ls.

The oxygen consumption rate of activated sludge in the biological selection, anaerobic, and anoxic pools is relatively small and ignored in the simulations. The DO concentration in the anoxic pool is regulated by the DO concentration at reflux, and in the oxic pool, by the consumption term of $\mathrm{DO}$ and the rate of oxygenation by the aeration device. The UDF defines the consumption term of DO, used as an input to the CFD software Fluent. The aeration device, a diaphragm aerator, produces bubbles of a small diameter across the aerobic pool. In order to reduce computing resources, the oxygen-increasing rate was directly defined for the entire aerobic pool water body.

\subsection{Geometry and Mesh Grid}

A three-dimensional model of the OD was established using the software Unigraphics NX (UG). Figure 2 shows a top view of meshed four ditch sections using triangle-shaped grids. The grid discrete area includes the whole flow channel and the runner area. An unstructured grid with good applicability is used for discretization of the complex channel, guide wall, and blade structure. In order to verify the grid independence, four different grid scales were selected to calculate the power of three blades, respectively. The electric power consumption tends to augment with mesh density, due to the higher accuracy of capturing the flow phenomenon around and outside the blades. The convergence of power is sufficiently met with a medium mesh density, of about 4.5 million elements. Table 1 
summarizes the breakdown of the elements utilized, along with the power consumption of the three blades. The final number of grids for each part is shown in Table 2.

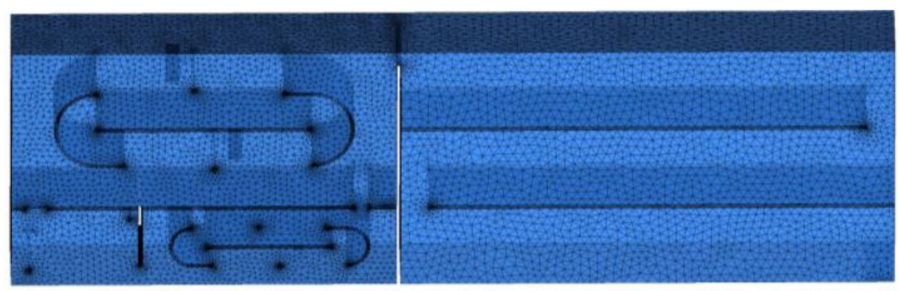

(a)

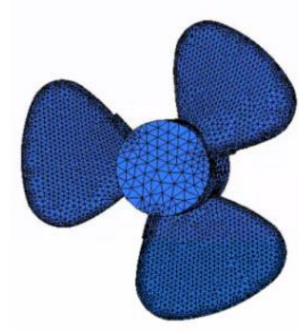

(b)

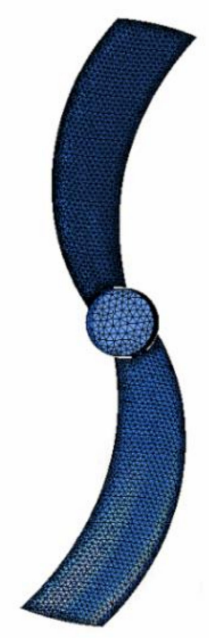

(c)

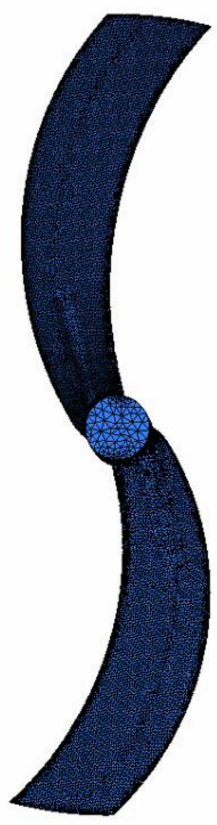

(d)

Figure 2. Meshed channel and blades of the OD. (a) The whole flow channel; (b) Agitators; (c) Propeller A; (d) Propeller B.

Table 1. Analysis of power consumption with mesh density.

\begin{tabular}{ccccc}
\hline Mesh Density & $\begin{array}{c}\text { Number of Elements } \\
\text { (Million) }\end{array}$ & $\begin{array}{c}\text { Consumed Power of Agitator } \\
\text { (Kw) }\end{array}$ & $\begin{array}{c}\text { Consumed Power of } \\
\text { Propeller A } \\
\text { (Kw) }\end{array}$ & $\begin{array}{c}\text { Consumed Power of } \\
\text { Propeller B (Kw) }\end{array}$ \\
\hline Coarse & 2.8 & 2.36 & 0.95 & 0.48 \\
Medium-coarse & 4.1 & 2.68 & 1.48 & 0.51 \\
Medium & 4.5 & 2.76 & 1.51 & 0.60 \\
Fine & 5.1 & 2.74 & 1.54 & 0.62 \\
\hline
\end{tabular}

Table 2. The number of grids per component.

\begin{tabular}{cccccc}
\hline & Flow Channel & Agitators & Propeller A & Propeller B & Total \\
\hline Number of elements & $2,546,813$ & $182,087 / 206,212$ & $226,986 / 239,570$ & $546,613 / 539,814$ & $4,488,095$ \\
\hline
\end{tabular}

\subsection{Experiments}

Monitoring tests are performed to compare and analyze the concentration of DO in different regions, whilst the specific field test method and a comparison with a numerical 
simulation can be found in Zhang et al. [18]. The DO monitoring instrument was an AZ8403 portable DO meter (Figure 3); the range of measurement was 0-19.99 mg/L, the accuracy was \pm 1.5 F.S, and the resolution was $0.01 \mathrm{mg} / \mathrm{L}$. Before the measurement, the saturated DO content was automatically calibrated according to the ambient temperature. During the measurement, one set of data was measured every $1 \mathrm{~s}$, and the data time length was $90 \mathrm{~s}$. A comparison of the mean simulated and measured (along with standard deviation) $\mathrm{DO}$ concentration in the four regions is shown in Figure 4. As can be seen, the simulations and DO concentrations in all areas are consistent, although the standard deviation in the oxic pool is much larger than in the other areas. These differences are explained by the action of the aeration device in the aerobic zone, resulting in the large local measurement fluctuations.

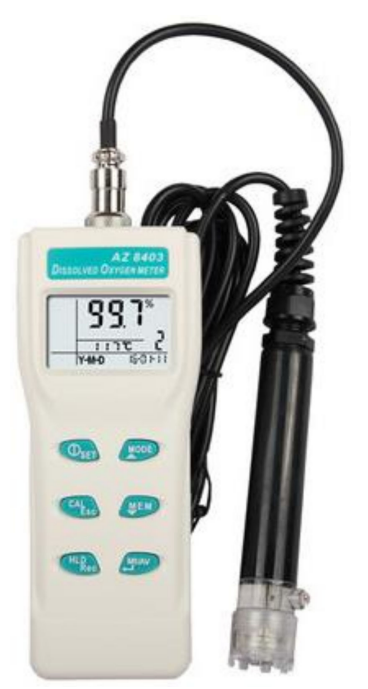

Figure 3. AZ8403 portable DO meter.

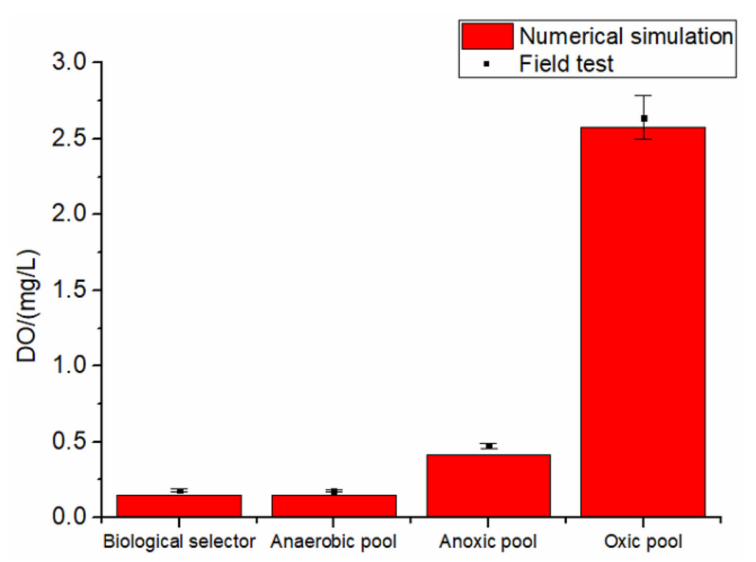

Figure 4. Comparison of the simulated average and measured DO concentrations in the four pools.

\section{Results and Discussion}

\subsection{Analysis of Velocity and Sludge Concentration}

A numerical approach was chosen for this exploratory study. Four X-Y cross sections at $0.3 \mathrm{~m}(0.05 \mathrm{H}), 1.8 \mathrm{~m}(0.3 \mathrm{H}), 3.8 \mathrm{~m}(0.63 \mathrm{H})$, and $5.7 \mathrm{~m}(0.95 \mathrm{H})$ were selected to observe the velocity distribution of the biological selection, anaerobic, and anoxic pools. The flow patterns with transversal height are shown in Figure 5. As expected, the agitators and propellers provide the energy to the water and drive the sludge within the sections and loops in the oval-shaped tanks. The water tends to be confined to the sides of the separating pool walls, forming two vortex structures in the biological selection pool and one behind the reflux slot, where energy is partially added to the anoxic pool. The biological selection 
pool shows large dead zones $(\mathrm{v}<0.1 \mathrm{~m} / \mathrm{s})$ at its corners and middle part, and these tend to augment with transversal height, as a result of the agitator's lower driving action near the water surface (hub height $=0.217 \mathrm{H}$ ). In the anaerobic pool, because of the propeller's large swept area and pushing action, the flow stagnates more around the curved than the middle diversion walls. Near the bottom, the propeller's presence is diminished, and dead zones can be observed at the middle diversion and short ends of the curved walls. The maximum flow velocity was obtained at the hub height, downstream of the propellers. In contrast to the anaerobic pool, the propeller action in the anoxic pool generated larger dead zones around the middle diversion than the curved wall, and these decreased with transversal height. This result is owing to the relatively large width of the runner and the proximity of the propeller to the curved diversion wall, resulting in the turning of the flow, prior to diffusion at both sides. The velocity of the propeller's downstream flow is still increased at hub height, but is exceeded by the reflux zone near the bed surface $(0.95 \mathrm{H})$.

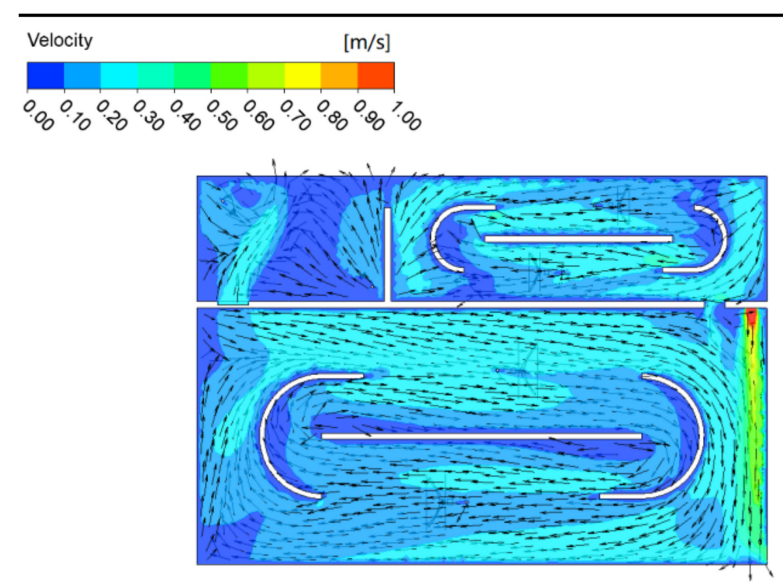

(a) $0.95 \mathrm{H}$

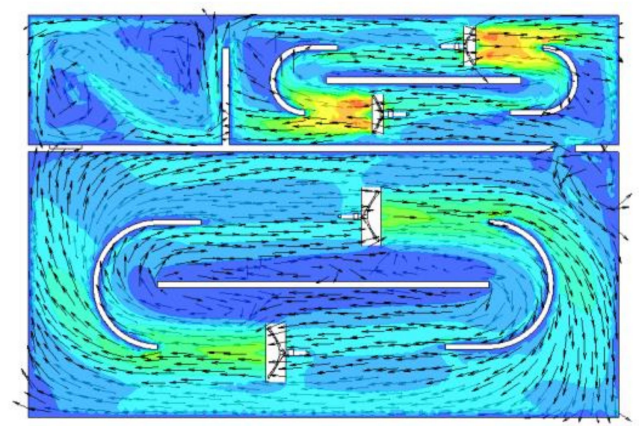

(c) $0.3 \mathrm{H}$

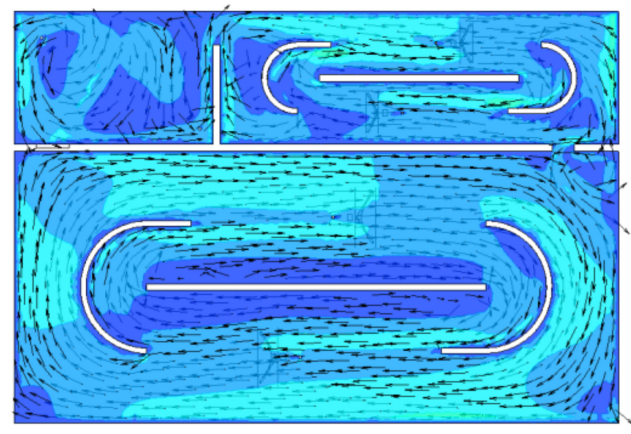

(b) $0.63 \mathrm{H}$

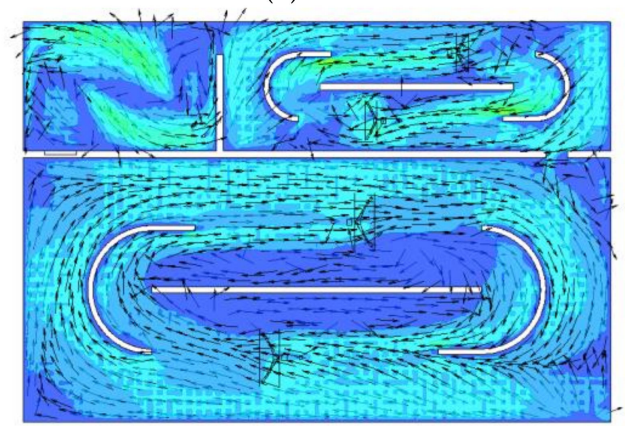

(d) $0.05 \mathrm{H}$

Figure 5. Velocity distribution in the OD at the $\mathrm{X}-\mathrm{Y}$ cross sections: $(\mathbf{a}) 0.95 \mathrm{H},(\mathbf{b}) 0.63 \mathrm{H},(\mathbf{c}) 0.3 \mathrm{H},(\mathbf{d}) 0.05 \mathrm{H}$.

Figure 6 shows the distribution of sludge concentrations at different bed heights. It can be seen how the sludge concentration in the biological selection pool is relatively high $(\sim 4.64 \mathrm{~g} / \mathrm{L})$, due to its role in cultivating the sludge, regardless of the studied depth. The zones around the oval-shaped diversion wall of the anaerobic and anoxic pools tend to manifest low volume fractions, owing to the large water circulation; although these tend to increase near the bed surface. Notably, the sludge concentration around the reflux zone is the highest near the bed surface, where flow is fast, but becomes homogeneous lower down. However, the same finding is not pertinent to the fast flows around the propellers, and it may be the case that the sludge concentrations are connected with the flow patterns resulting from the pushing of the propellers and hitting the walls. Therefore, there is no obvious correlation between the local velocity and sludge concentration, as depicted in Figures 5 and 6. 
Phase 2 Concentration

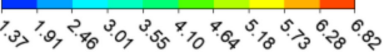

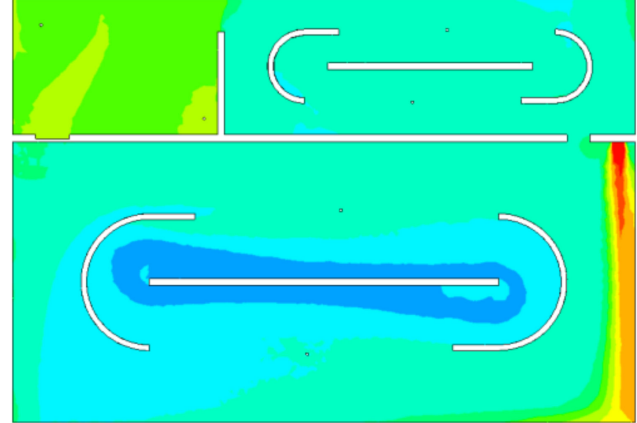

(a) $0.95 \mathrm{H}$

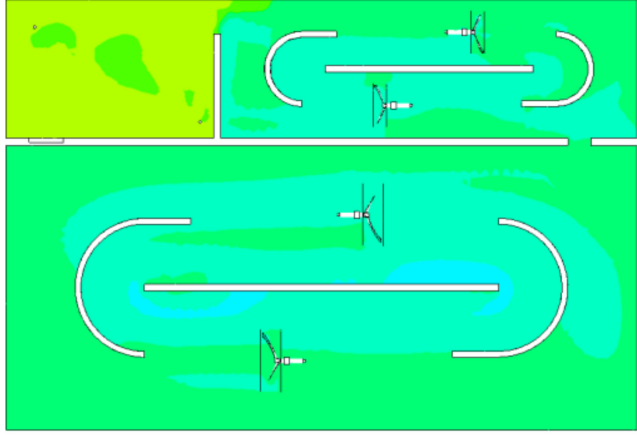

(c) $0.3 \mathrm{H}$

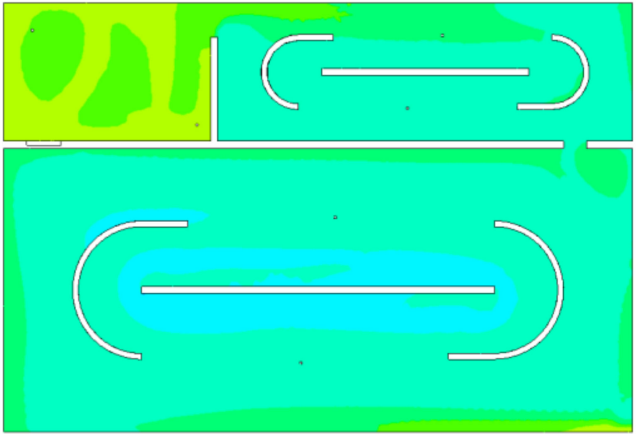

(b) $0.63 \mathrm{H}$

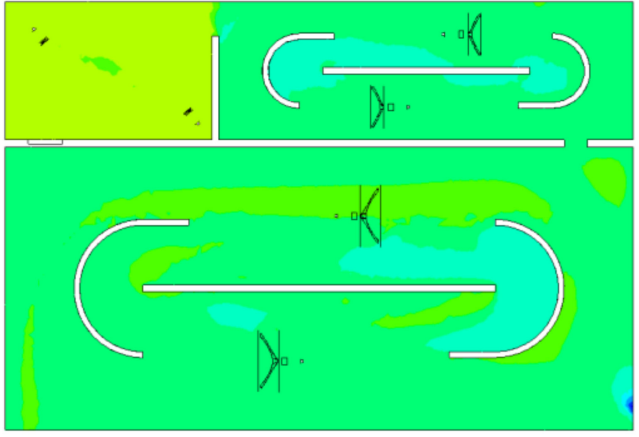

(d) $0.05 \mathrm{H}$

Figure 6. Sludge concentration in the OD at the $X-Y$ cross sections: (a) $0.95 \mathrm{H},(\mathbf{b}) 0.63 \mathrm{H},(\mathbf{c}) 0.3 \mathrm{H}$, (d) $0.05 \mathrm{H}$.

To further analyze the relationship between flow rate and sludge settlement, the curves of average velocity and sludge concentration of the three pools with transverse distance are drawn in Figures 7 and 8. It can be seen that the average sectional velocities in the three pools increased and decreased between $Z=0$ and $Z=3.5$, and peaked at the height of the corresponding agitators or propellers: $0.25 \mathrm{~m} / \mathrm{s}$ for the biological selection pool, $0.28 \mathrm{~m} / \mathrm{s}$ for the anaerobic pool, and $0.21 \mathrm{~m} / \mathrm{s}$ for the anoxic pool. Thereafter, the velocities of the flow tended to stabilize for the biological selection and anaerobic pool, but increased again for the anoxic pool; it is, therefore, likely such trend is connected with the reflux slot. The sludge concentration in the OD decreased overall with height and the ratio of minimum to maximum sludge concentration varied for each pool: $4.55 / 4.76=0.96$ for biological selection, 3.3/3.7 $=0.89$ for anaerobic, $3.1 / 4=0.775$ for anoxic. These results indicate that the sludge is both greater and more concentrated in the biological selection than in the other pools. Figure 9 depicts the areas (blue) of the three-dimensional OD with a sludge concentration greater than $3.7 \mathrm{~g} / \mathrm{L}$. High concentrations are observed around the whole biological selection pool, bottom and inlet of the anaerobic tank, flow path of the reflux slot, and walls of the anoxic pool. The largest range, and the majority of the extreme sludge concentration values simulated (Figure 10), pertained to the biological selection pool. Notably, the areas of high sludge concentration at the bottom of the OD contain slow flows. 


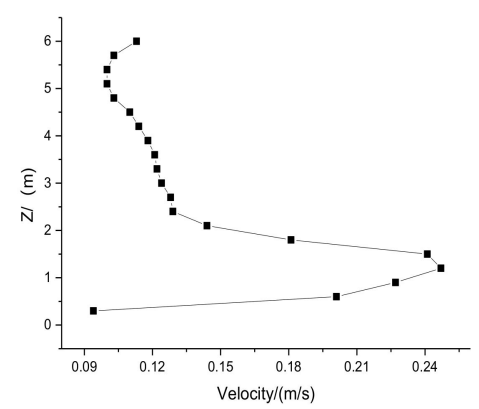

(a)

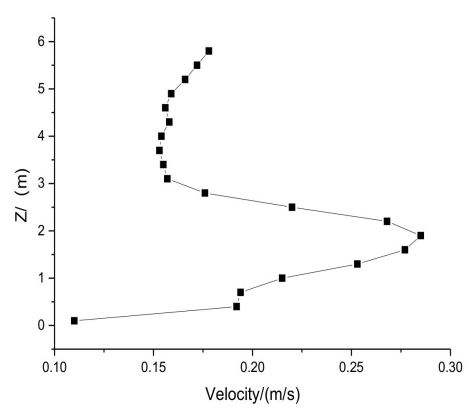

(b)

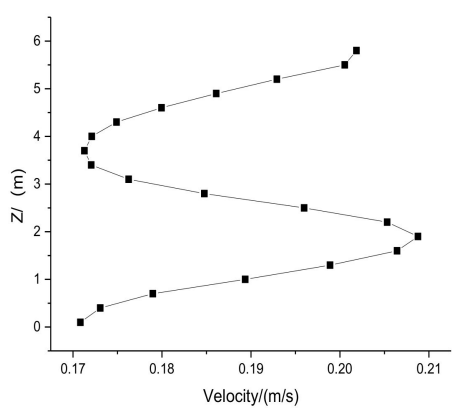

(c)

Figure 7. Curves of average velocity at each section. (a) Biological selection pool; (b) Anaerobic pool; (c) Anoxic pool.

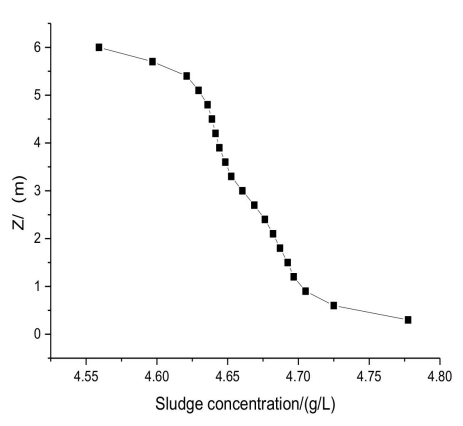

(a)

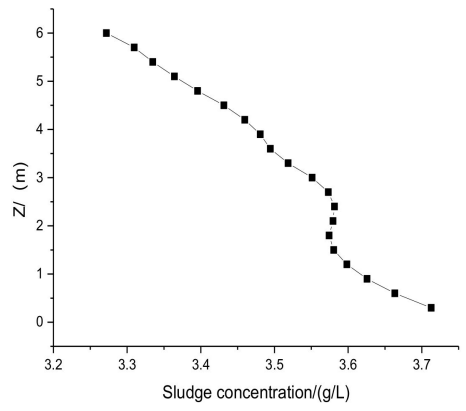

(b)

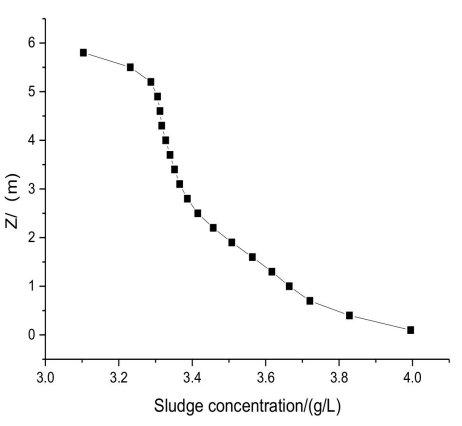

(c)

Figure 8. Curves of average sludge concentration at each section. (a) Biological selection pool; (b) Anaerobic pool; (c) Anoxic pool.

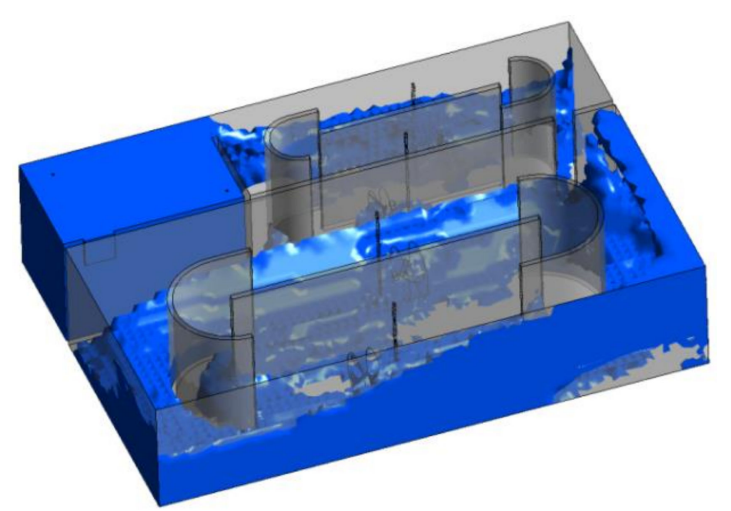

Figure 9. Sludge deposit area.

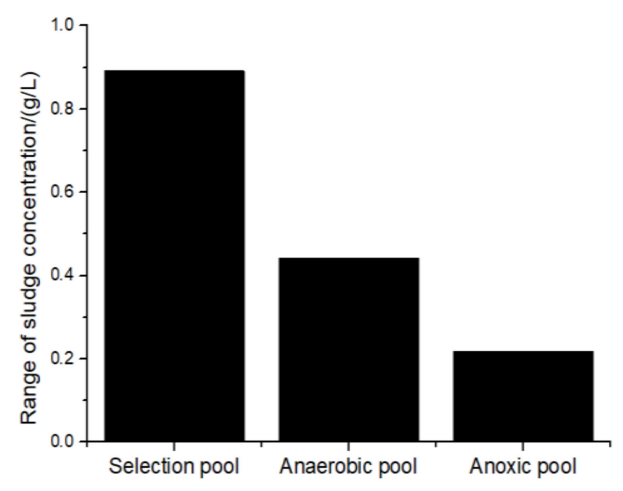

Figure 10. Range of sludge concentration. 


\subsection{Analysis of DO Concentration}

\subsubsection{Factors Affecting the DO Concentration}

The mean DO concentrations of the anoxic pool and reflux slot, and of the oxic pool and oxygenation rate of the aeration device, are examined in Figure 11; to offer a model for evaluating the effectiveness of the oxidation ditch. As observed, both tank variables can be fitted as:

$$
C_{A}=0.18 C_{R}^{2}+0.14 C_{R}+0.18
$$

where $C_{A}$ is the mean DO concentration in the anoxic zone, $\mathrm{mg} / \mathrm{L}$, and $C_{R}$ is DO concentration at the reflux slot, $\mathrm{mg} / \mathrm{L}$.

$$
C_{O}=0.14 V_{A}^{2}+0.42-2.10
$$

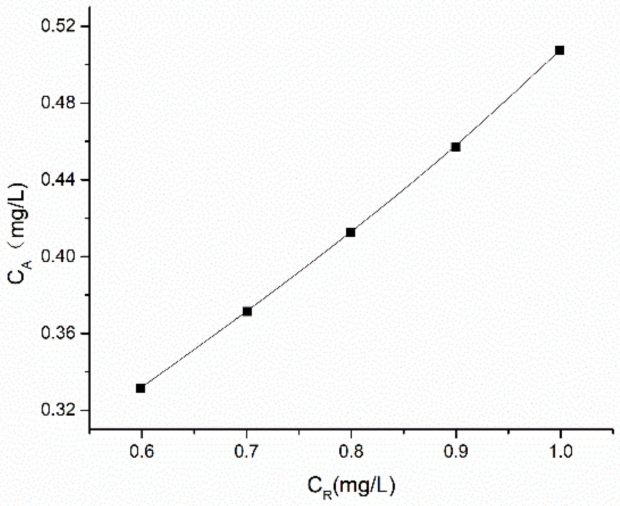

(a)

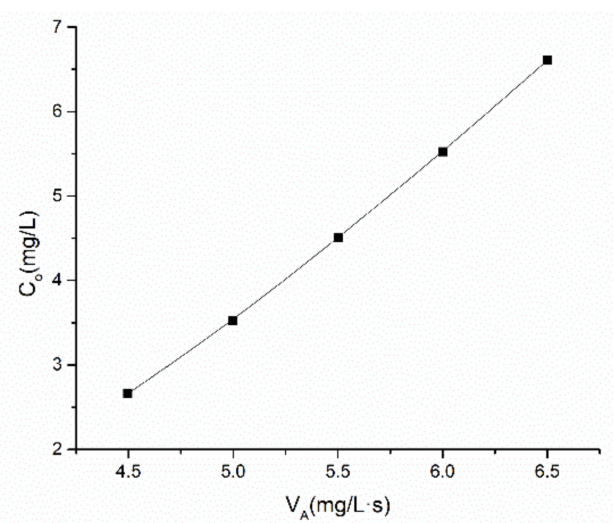

(b)

Figure 11. The relationship between the average DO concentration and the reflux slot and aerators. (a) Reflux slot; (b) Aerators.

With $C_{O}$ being the mean DO concentration in the oxic pool, $\mathrm{mg} / \mathrm{L}$, and $V_{A}$ the oxygenation rate of the aeration device, $\mathrm{mg} / \mathrm{L}$.

In the treatment process, to ensure the normal occurrence of the reaction, the $\mathrm{DO}$ in the aerobic pool should be $2-4 \mathrm{mg} / \mathrm{L}$, whilst at the anaerobic pool it should be $0.20-0.50 \mathrm{mg} / \mathrm{L}$, giving a DO of $0.31-0.99 \mathrm{mg} / \mathrm{L}$ at the reflux slot.

\subsubsection{Analysis of DO Distribution}

In the studied scenario, the concentration of DO in the reflux slot was $0.8 \mathrm{mg} / \mathrm{L}$ and in the aeration pool, $5 \mathrm{mg} / \mathrm{Ls}$. This DO distribution is illustrated in Figures 12-14. It is evident the conditions of anaerobic bacterial reaction are met, since the DO in both the biological selection and the anaerobic pool are uniform and below $0.2 \mathrm{mg} / \mathrm{L}$, and in the anoxic pool around $0.5 \mathrm{mg} / \mathrm{L}$; except at the transition zone, the reflux area. As the DO concentration at the inlet is controlled to a low level, the DO in the reflux zone is augmented with transverse distance, peaking at $0.8 \mathrm{mg} / \mathrm{L}$, near the bed surface (Figure 12a). When the sewage flows into the oxic pool, the DO concentration gradually increases under the influence of the aerator's oxygenation rate and DO consumption rate, thus the DO is higher transversally, laterally, and along the flow direction (Figure 13). As a result, the concentrations of DO in the first and second flow-passing sections are lower near their entrances, whilst in the third section, the DO increases in the exit zone and becomes high and homogenous across the entire section near the bed surface. 


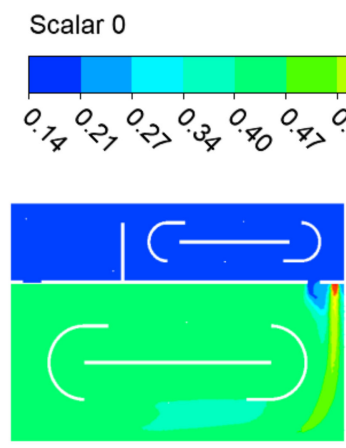

(a)

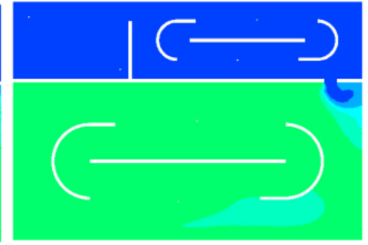

(b)

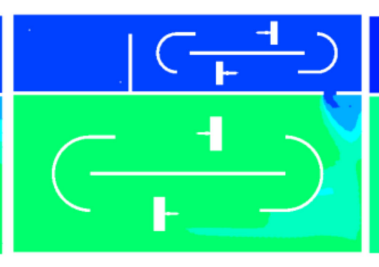

(c)

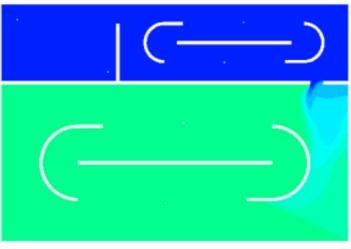

(d)

Figure 12. DO concentration contours of the biological selection pool, anaerobic pool, and anoxic pool at different heights. (a) $0.95 \mathrm{H}$, (b) $0.63 \mathrm{H}$, (c) $0.3 \mathrm{H}$, (d) $0.05 \mathrm{H}$.

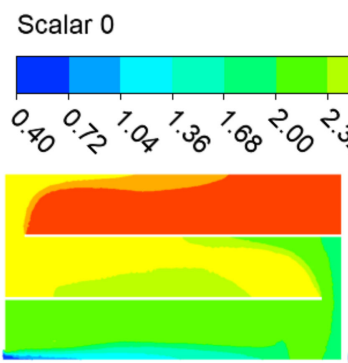

(a)

$[\mathrm{mg} / \mathrm{L}]$

(1)

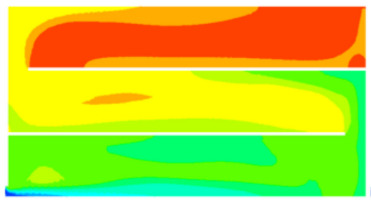

(b)

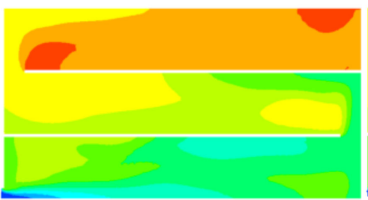

(c)

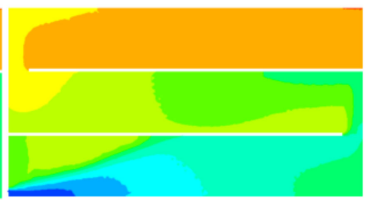

(d)

Figure 13. DO concentration contours of the oxic pool at different heights. (a) $0.95 \mathrm{H}$, (b) $0.63 \mathrm{H}$, (c) $0.3 \mathrm{H},(\mathbf{d}) 0.05 \mathrm{H}$.

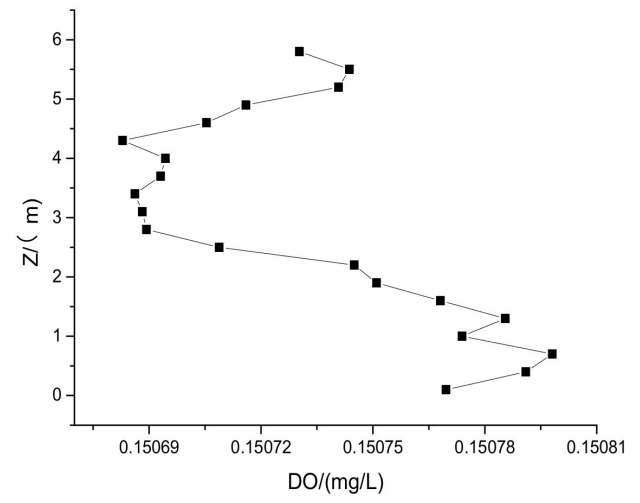

(a)

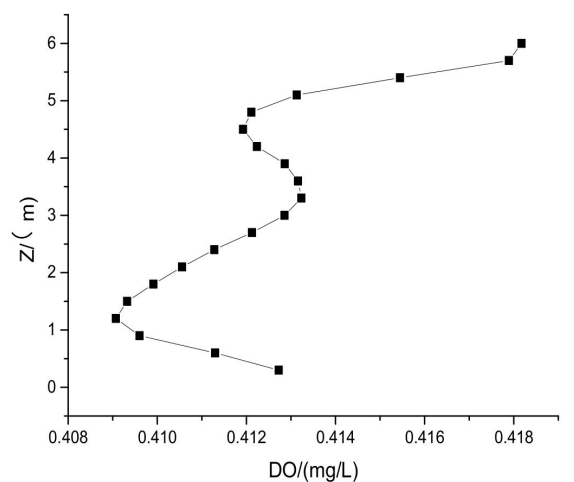

(c)

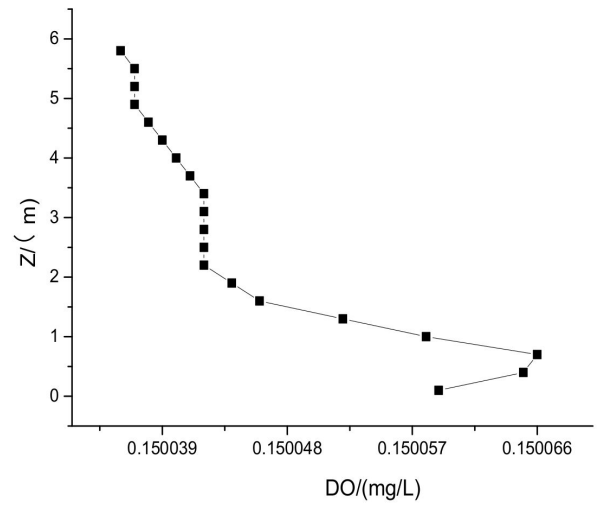

(b)

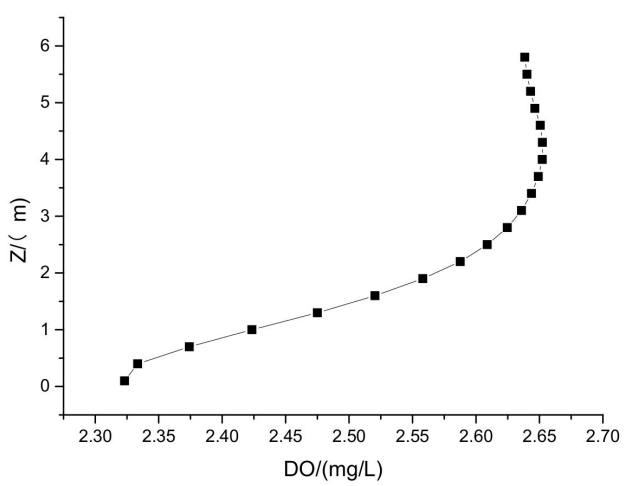

(d)

Figure 14. Curves of average DO concentration at each section. (a) Biological selection pool; (b) Anaerobic pool; (c) Anoxic pool; (d) Oxic pool. 
In order to obtain further information about the oxygen distribution, the transverse DO concentration of the four pools is calculated in Figure 14. Clearly, the DO remains constant at $0.15 \mathrm{mg} / \mathrm{L}$ for the biological selection and anaerobic pools, and at $0.412 \mathrm{mg} / \mathrm{L}$ for the anoxic pool, but increases transversally from $2.3 \mathrm{mg} / \mathrm{L}$ and plateaus to $2.65 \mathrm{mg} / \mathrm{L}$ at $\mathrm{Z}=4$ for the oxic pool.

\subsection{Effect of Rotation Speed Change on the $O D$}

The influence of rotation speed on the distribution of velocity, sludge, and DO with height were investigated in the three pools by adding and subtracting $50 \mathrm{rpm}$ to the agitators' original state $\left(\omega_{\mathrm{a}} \pm 9.1 \%\right)$ and $10 \mathrm{rpm}$ to the propellers' $\left(\omega_{p} \pm 25.64 \%\right)$.

Figure 15 shows the velocity, sludge concentration, and DO changes with height in different zones. As observed, the increasing rotational speed of the agitators and propellers slightly shifted the original sludge and DO distributions, but considerably shifted the velocity distribution to the right; particularly, the velocity around the hub for the biological selection and anaerobic pool and for all of the anoxic pool. This is because the sludge was inhomogeneous in the biological selection pool with low rotation speeds, so it accumulated in the anaerobic pool and anoxic pool. These trends also indicate that the sludge distribution becomes more uniform with higher rotation speed.
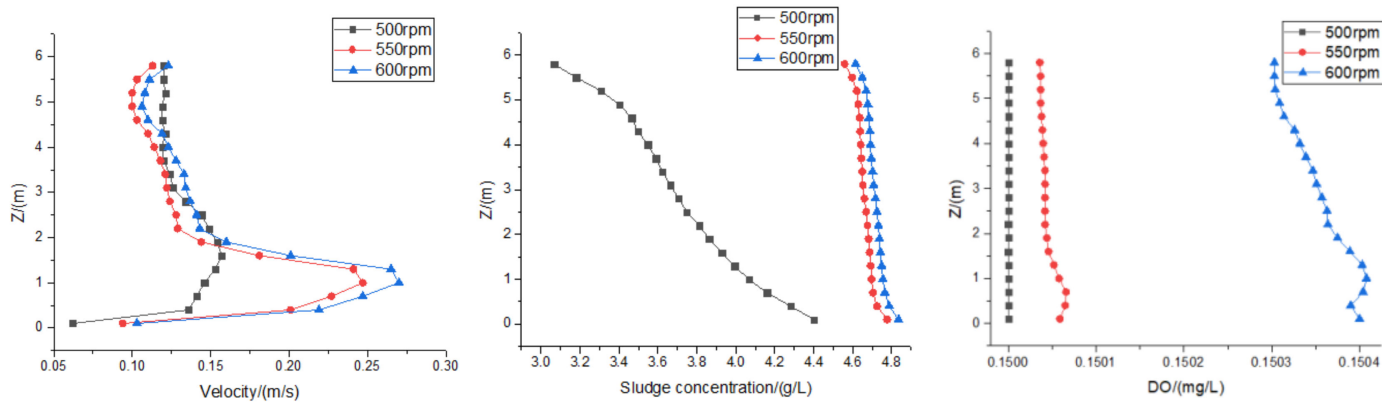

(a)
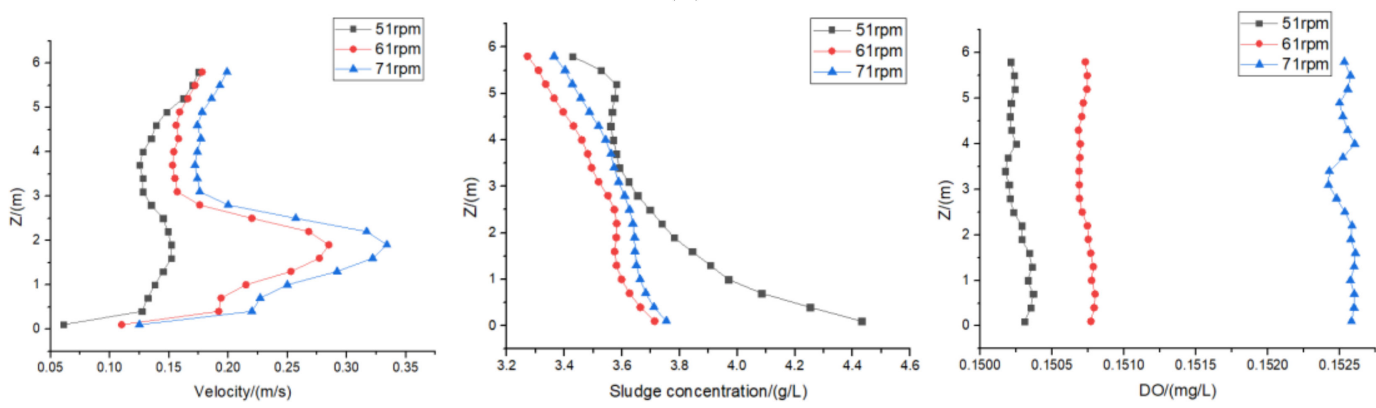

(b)
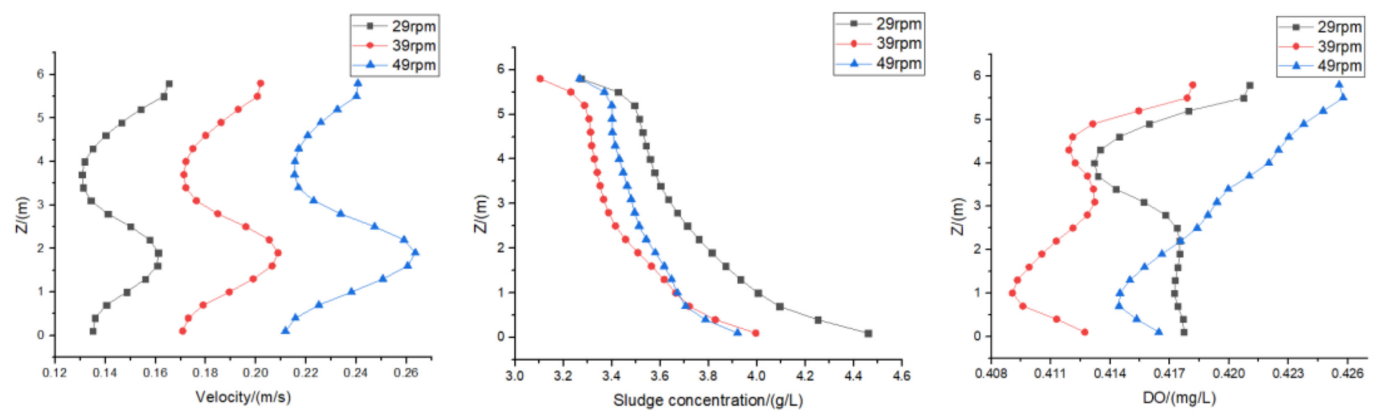

(c)

Figure 15. Curves of average velocity, sludge concentration, and DO concentration at each section. (a) Biological selection pool; (b) Anaerobic pool; (c) Anoxic pool. 
On the other hand, reducing the rotation speed resulted in the original DO being shifted slightly to lower values for the biological selection and anaerobic pools but to greater values for the anoxic pool; notably, the DO was the highest around and below the propeller swept region with a constant value $(0.417 \mathrm{mg} / \mathrm{L})$. The velocity augmentation at the agitator and propeller hub position only become prominent in the anoxic pool; thus, the velocity of the other two pools remained somewhat constant with depth. Contrastingly, the sludge concentration decreased with height, but remained much lower in the biological selection pool and was slightly higher for the anaerobic and anoxic pools, compared with the other two cases.

\section{Conclusions}

The distribution of velocity, sludge, and DO in a full-scale A2/O OD was simulated using a mixture multi-phase flow model. Detailed depth variation analyses of the sewage flow were provided for the biological selection, anaerobic, and anoxic pools using standard, higher, and lower propeller and agitator rotation speeds.

Due to the circulation of the water, geometrical obstructions, and the position of the propellers or agitators, dead zones appeared at the corners and separating walls; particularly at the top of the middle diversion wall of the anoxic tank. This research has shown that the sludge settlement is the greatest in the biological selection pool, due to its cultivation role, and the reflux slot slightly accelerates the bottom flow in the anoxic pool, resulting in considerable sludge concentration. A major finding was the lack of correlation between local velocity and sludge concentration; the areas with a large sludge concentration at the biological selection pool were generally slow-velocity flows, whilst at the anoxic pool (near the bed surface and reflux zone) they were high-velocity flows.

A linear relationship was found between the reflux slot and the mean anoxic DO concentration, and between the mean aerobic pool concentration and the oxygenation rate of the aerator; implying that different conditions can be configured with the design of the reflux slot. The flow rate of the reflux slot and the oxygenation rate of the aerator were verified to reside within the acceptable limits for bacterial reaction.

As the radius of the propeller increases, its influence on the overall velocity gradually increases, due to the larger rotor to bed cross-section. With the increase of the rotation speed, the change of sludge concentration becomes more uniform in the biological selection, anaerobic, and anoxic pools. The flow velocity in the pools increases with the rotation speed; therefore, the observed high DO concentration in the inlet and the reflux slot could be higher and more evenly distributed across the anaerobic pool. Importantly, having lower agitator and propeller rotation speeds decreases the sludge concentrations in the biological selection pool, where most sludge is deposited in the sewage plant. Therefore, selecting the appropriate propeller operation, based on the water quality requirements of the oxidation ditch, can serve as a methodology to homogenize the sludge concentrations in the chambers, increasing the life expectancy of the wastewater plant. However, the generalizability of the presented results is limited to similar wastewater treatment plants. Thus, additional studies will be needed to determine this trend of reduction with hub positioning and a larger range of rotation speeds of the agitator and propeller.

Author Contributions: Conceptualization, C.L. and Z.H.; Formal analysis, Y.Z. (Yuquan Zhang); Investigation, Z.H.; Methodology, C.L.; Project administration, Z.H.; Supervision, Y.Z. (Yuquan Zhang) and Y.Z. (Yuan Zheng); Validation, E.F.-R.; Writing—original draft, C.L.; Writing—review \& editing, Y.Z. (Yuquan Zhang), H.Z. and E.F.-R. All authors have read and agreed to the published version of the manuscript.

Funding: The research was supported by the following funding programs: Postgraduate Research and Practice Innovation Program of Jiangsu Province, China (No. KYCX21_0519).

Institutional Review Board Statement: Not applicable.

Informed Consent Statement: Not applicable. 


\section{Data Availability Statement: Not applicable.}

Conflicts of Interest: The authors declare no conflict of interest.

\section{Nomenclature}

\begin{tabular}{|c|c|c|}
\hline OD & Oxidation ditch & $\mathrm{A} 2 / \mathrm{O}$ \\
\hline WWTP & Wastewater treatment plants & DO \\
\hline ADV & Acoustic Doppler Velocimeter & CFD \\
\hline ASM 2 & Activated Sludge Model No. 2 & UDF \\
\hline UDS & user-defined source & $\rho_{m}$ \\
\hline $\bar{v}_{m}$ & average velocity of the mass, $\mathrm{m} / \mathrm{s}$ & $\mu_{m}$ \\
\hline$\vec{F}$ & volume force, $\mathrm{N}$ & $\mathrm{n}$ \\
\hline$\alpha_{k}$ & volume fraction of the kth phase & $\rho_{k}$ \\
\hline $\bar{v}_{d r . k}$ & drift velocity of the kth phase, $\mathrm{m} / \mathrm{s}$ & $\bar{v}_{d r . p}$ \\
\hline$\mu_{s v}$ & sludge viscosity, 10-3 Pa.s & $\mathrm{T}$ \\
\hline MLSS & sludge concentration, $\mathrm{g} / \mathrm{L}$ & Vs \\
\hline $\mathrm{x}$ & sludge concentration, $\mathrm{g} / \mathrm{L}$ & $\phi$ \\
\hline $\mathrm{U}$ & fluid velocity vector & $\Gamma$ \\
\hline S & source term representing creation or destruction of $\phi$ & BOD \\
\hline AOR & actual oxygen demand, $\mathrm{kgO}_{2} / \mathrm{d}$ & a \\
\hline Q & daily average water mass flow, $\mathrm{kg} / \mathrm{s}$ & $\mathrm{t}$ \\
\hline$\Delta \mathrm{C}_{\mathrm{BOD}}$ & $\begin{array}{l}\text { BOD concentration difference of inlet and out- } \\
\text { let, } \mathrm{mg} / \mathrm{L}\end{array}$ & $\mathrm{b}$ \\
\hline MLSS $_{\mathrm{o}}$ & sludge concentration of oxic pool, g/L & $\mathrm{V}_{\mathrm{o}}$ \\
\hline c & $\begin{array}{l}\text { oxygen demand per kilogram of ammonia and nitro- } \\
\text { gen removed }\end{array}$ & $\Delta \mathrm{C}_{\mathrm{NH} 3-\mathrm{N}}$ \\
\hline SOR & standard oxygen demand, $\mathrm{kgO}_{2} / \mathrm{d}$ & $\mathrm{T}_{\max }$ \\
\hline $\mathrm{C}_{\mathrm{s} 20}$ & $\begin{array}{l}\text { saturated DO concentration at } 20^{\circ} \mathrm{C} \text { under standard } \\
\text { atmospheric pressure, } \mathrm{mg} / \mathrm{L}\end{array}$ & $\alpha$ \\
\hline$\beta$ & $\begin{array}{l}\text { correction factor for saturated DO concentration in } \\
\text { sewage }\end{array}$ & $\rho$ \\
\hline $\mathrm{C}_{1}$ & concentration of DO in the sewage, $\mathrm{mg} / \mathrm{L}$ & $\mathrm{C}_{\mathrm{cv}}$ \\
\hline $\mathrm{OUR}_{\max }$ & maximum consumption rate of $\mathrm{DO}, \mathrm{mg} / \mathrm{Ls}$ & $\mathrm{C}_{\mathrm{A}}$ \\
\hline $\begin{array}{l}C_{R} \\
V_{A}\end{array}$ & $\begin{array}{l}\text { DO concentration at the reflux slot, } \mathrm{mg} / \mathrm{L} \text {. } \\
\text { the oxygenation rate of the aeration device, } \mathrm{mg} / \mathrm{L} \text {. }\end{array}$ & $\mathrm{C}_{\mathrm{O}}$ \\
\hline
\end{tabular}

\author{
Anaerobic-Anoxic-Oxic process \\ Dissolved oxygen \\ Computational Fluid Dynamics \\ user-defined function \\ mixture density, $\mathrm{kg} / \mathrm{m}^{3}$ \\ viscosity coefficient of the mixture, $\mathrm{Pa} \cdot \mathrm{s}$ \\ number of phase \\ density of the $\mathrm{kth}$ phase, $\mathrm{kg} / \mathrm{m}^{3}$ \\ slip velocity of the second phase $(\mathrm{p})$ relative to the \\ main phase $(\mathrm{q}), \mathrm{m} / \mathrm{s}$ \\ absolute temperature, $\mathrm{K}$ \\ sludge sedimentation rate, $\mathrm{m} / \mathrm{s}$ \\ dissipation function \\ diffusion coefficient, $\mathrm{m}^{2} / \mathrm{s}$ \\ biochemical oxygen demand \\ oxygen demand for each removal of $1 \mathrm{~kg}$ BOD \\ Temperature, ${ }^{\circ} \mathrm{C}$ \\ oxygen demand per kilogram of oxic sludge for its \\ own respiration \\ volume of the oxic pool, $\mathrm{L}$ \\ difference in ammonia and nitrogen concentration \\ between the inlet and outlet \\ maximum designed water temperature, ${ }^{\circ} \mathrm{C}$ \\ correction factor of oxygen transfer coefficient in \\ sewage \\ correction factor for air pressure
}

concentration of DO in the control volume, $\mathrm{mg} / \mathrm{L}$ the mean DO concentration in the anoxic zone, $\mathrm{mg} / \mathrm{L}$

mean DO concentration in the oxic pool, $\mathrm{mg} / \mathrm{L}$

\section{References}

1. Singh, K.P.; Mohan, D.; Sinha, S.; Dalwani, R. Impact assessment of treated/untreated wastewater toxicants discharged by sewage treatment plants on health, agricultural, and environmental quality in the wastewater disposal area. Chemosphere 2004, 55, 227-255. [CrossRef] [PubMed]

2. Helal, A.; Ghoneim, W.; Halaby, A. Feasibility Study for Self-Sustained Wastewater Treatment Plants-Using Biogas CHP Fuel Cell, Micro-Turbine, PV and Wind Turbine Systems. Smart Grid Renew. Energy 2013, 04, 227-235. [CrossRef]

3. Liu, W.; Wu, Y.; Zhang, S.; Gao, Y.; Jiang, Y.; Horn, H.; Li, J. Successful granulation and microbial differentiation of activated sludge in anaerobic/anoxic/aerobic $(\mathrm{A}(2) \mathrm{O})$ reactor with two-zone sedimentation tank treating municipal sewage. Water Res. 2020, 178, 115825. [CrossRef]

4. Wang, H.C.; Cui, D.; Han, J.L.; Cheng, H.Y.; Liu, W.Z.; Peng, Y.Z.; Chen, Z.B.; Wang, A.J. A(2)O-MBR as an efficient and profitable unconventional water treatment and reuse technology: A practical study in a green building residential community. Resour. Conserv. Recycl. 2019, 150, 12. [CrossRef]

5. Jin, L.Y.; Zhang, G.M.; Tian, H.F. Current state of sewage treatment in China. Water Res. 2014, 66, 85-98. [CrossRef]

6. Yang, M.; Sun, P.; Wang, R.; Han, J.; Wang, J.; Song, Y.; Cai, J.; Tang, X. Simulation and optimization of ammonia removal at low temperature for a double channel oxidation ditch based on fully coupled activated sludge model (FCASM): A full-scale study. Bioresour. Technol. 2013, 143, 538-548. [CrossRef] [PubMed]

7. Hanjra, M.A.; Qureshi, M.E. Global water crisis and future food security in an era of climate change. Food Policy 2010, 35, 365-377. [CrossRef]

8. Matko, T.; Chew, J.; Wenk, J.; Chang, J.; Hofman, J. Computational fluid dynamics simulation of two-phase flow and dissolved oxygen in a wastewater treatment oxidation ditch. Process. Saf. Environ. Prot. 2021, 145, 340-353. [CrossRef] 
9. Zhang, Y.; Zang, W.; Zheng, J.; Cappietti, L.; Zhang, J.; Zheng, Y.; Fernandez-Rodriguez, E. The influence of waves propagating with the current on the wake of a tidal stream turbine. Appl. Energy 2021, 290, 116729. [CrossRef]

10. Zhang, Y.; Zhang, Z.; Zheng, J.; Zhang, J.; Zheng, Y.; Zang, W.; Lin, X.; Fernandez-Rodriguez, E. Experimental investigation into effects of boundary proximity and blockage on horizontal-axis tidal turbine wake. Ocean. Eng. 2021, 225, 108829. [CrossRef]

11. Mir, E.; Rashidi, H.; Valeh-e-Sheyda, P. Towards a CFD-based analysis of a full-scale sludge tank to enhance dewatering capacity of the downstream filter press. Process. Saf. Environ. Prot. 2018, 120, 166-177. [CrossRef]

12. Chen, L.; Feng, Q. Two-Phase Flow Model Applied in the Oxidation Ditch. Adv. Mater. Res. 2013, 838-841, 1659-1662. [CrossRef]

13. Zhang, Y.; Zheng, Y.; Fernandez-Rodriguez, E.; Yang, C.; Zhu, Y.; Liu, H. Optimization design of submerged propeller in oxidation ditch by computational fluid dynamics and comparison with experiments. Water Sci. Technol. 2016, 74, 681-690. [CrossRef]

14. Wei, J.H.; Xu, Z.Q. CFD method for the relationship between the radius size of impellers and cross-sectional average velocity of flow in an oxidation ditch. Desalination Water Treat. 2018, 126, 127-134. [CrossRef]

15. Littleton, H.X.; Daigger, G.T.; Storm, P.F. Application of computational fluid dynamics to closed-loop bioreactors: I. Characterization and simulation of fluid-flow pattern and oxygen transfer. Water Environ. Res. 2007, 79, 600-612. [CrossRef] [PubMed]

16. Littleton, H.X.; Daigger, G.T.; Strom, P.F. Application of computational fluid dynamics to closed-loop bioreactors: II. Simulation of biological phosphorus removal using computational fluid dynamics. Water Environ. Res. 2007, 79, 613-624. [CrossRef]

17. Xie, H.; Yang, J.; Hu, Y.; Zhang, H.; Yang, Y.; Zhang, K.; Zhu, X.; Li, Y.; Yang, C. Simulation of flow field and sludge settling in a full-scale oxidation ditch by using a two-phase flow CFD model. Chem. Eng. Sci. 2014, 109, 296-305. [CrossRef]

18. Zhang, Y.; Li, C.; Xu, Y.; Tang, Q.; Zheng, Y.; Liu, H.; Fernandez-Rodriguez, E. Study on Propellers Distribution and Flow Field in the Oxidation Ditch Based on Two-Phase CFD Model. Water 2019, 11, 12. [CrossRef]

19. Zhang, P.; Wu, Z.; Ao, H. Experimental deduction of the relationship between sludge viscidity, concentration and temperature. Chin. J. Environ. Eng. 2006, 7, 72-74.

20. Xu, Q.; Yang, J.; Hou, H.; Hu, Y.; Liang, S.; Xiao, K.; Wu, X.; Liu, B.; Hu, J.; Hu, J.; et al. Simulation on flow field and gas hold-up of a pilot-scale oxidation ditch by using liquid-gas CFD model. Water Sci. Technol. 2018, 78, 1956-1965. [CrossRef]

21. Höhne, T.; Mamedov, T. CFD Simulation of Aeration and Mixing Processes in a Full-Scale Oxidation Ditch. Energies 2020, 13, 7. [CrossRef]

22. Yang, Y.; Yang, J.; Zuo, J.; Li, Y.; He, S.; Yang, X.; Zhang, K. Study on two operating conditions of a full-scale oxidation ditch for optimization of energy consumption and effluent quality by using CFD model. Water Res. 2011, 45, 3439-3452. [CrossRef] [PubMed]

23. Kulkarni, A.A. Mass transfer in bubble column reactors: Effect of bubble size distribution. Ind. Eng. Chem. Res. 2007, 46, e2205-e2211. [CrossRef]

24. Lei, L.; Ni, J. Three-dimensional three-phase model for simulation of hydrodynamics, oxygen mass transfer, carbon oxidation, nitrification and denitrification in an oxidation ditch. Water Res. 2014, 53, 200-214. [CrossRef] [PubMed]

25. Climent, J.; Martínez-Cuenca, R.; Carratalà, P.; González-Ortega, M.J.; Abellán, M.; Monrós, G.; Chiva, S. A comprehensive hydrodynamic analysis of a full-scale oxidation ditch using Population Balance Modelling in CFD simulation. Chem. Eng. J. 2019, 374, 760-775. [CrossRef]

26. Leighton, D.; Acrivos, A. The shear-induced migration of particles in concentrated suspensions. J. Fluid Mech. 1987, 181, 415-439. [CrossRef] 